Swarthmore College

Works

$1-1-2014$

\title{
Why Liberal Arts Colleges Can Often Do Political Science Better Than Big Research Institutions: A Reflection From An Americanist
}

Carol Nackenoff

Swarthmore College, cnacken1@swarthmore.edu

Follow this and additional works at: https://works.swarthmore.edu/fac-poli-sci

Part of the Political Science Commons

Let us know how access to these works benefits you

\section{Recommended Citation}

Carol Nackenoff. (2014). "Why Liberal Arts Colleges Can Often Do Political Science Better Than Big Research Institutions: A Reflection From An Americanist". Polity. Volume 46, Issue 1. 98-106. DOI: 10.1057/pol.2013.30 https://works.swarthmore.edu/fac-poli-sci/83

This work is brought to you for free by Swarthmore College Libraries' Works. It has been accepted for inclusion in Political Science Faculty Works by an authorized administrator of Works. For more information, please contact myworks@swarthmore.edu. 


\title{
Why Liberal Arts Colleges Can Often Do Political Science Better than Big Research Institutions: A Reflection from an Americanist
}

\author{
Carol Nackenoff \\ Swarthmore College
}

By supporting new course development and by encouraging cross-disciplinary conversations and collaborations, liberal arts colleges can often help political scientists expand their capacities beyond narrow disciplinary "silos," with benefits for faculty and students alike. At the same time, it is important to teach political science students what our own discipline has to offer, to help students understand our discipline's strengths, and to borrow when confronted with moments when explanatory frameworks of the discipline fail. Liberal arts departments begin the training of many future Ph.D.s; however, our job is not only to equip students to do further work within the discipline but also to use its tools to become engaged and astute democratic citizens who can analyze, interpret, and evaluate policies and political developments around them.

Polity (2014) 46, 98-106. doi:10.1057/pol.2013.30; published online 28 October 2013

Keywords liberal arts; political science; American politics; teaching

What, if anything, is distinctive about the way we teach, or should teach, political science in the liberal arts setting? And is the liberal arts setting in some ways better for teaching political science?

I have some basis for comparison: I began my career in a research university and have been happily working in a liberal arts setting for many years. At that university, I taught in a large department that included dozens of Americanists, whose specialties were further classified as either institutional or behavioral. My graduate training was both in political theory and in American politics broadly

Thanks to Austin Sarat and Amrita Basu for organizing the conference for which this paper was written, and thanks to the other conference participants for a stimulating discussion. I would also like to thank Ernie Zirakzadeh, editor of Polity, for serving as editor of this symposium collection, and other members of the Polity staff for their helpful suggestions. 
conceived, making me hard to classify. But I completed a dissertation that was survey research based, and was therefore an Americanist and a behavioralist in the research university. I no longer teach most of the political behavior courses I was asked to teach when first hired, and I no longer analyze survey research. My 1994 book (The Fictional Republic) would not have been recognized as political sciencemuch less as American politics_-at a number of research universities.

Teaching in liberal arts colleges has allowed me to be a different, happier kind of teacher and scholar. These liberal arts institutions provided financial support, time, space, and encouragement to engage in course development, so that I could expand my teaching capacities. I followed my interests as well as institutional needs as I developed courses in constitutional law, environmental politics and policy, and gender and politics. I have appreciated the opportunity to read, teach, and sometimes write about issues raised in these varied areas of inquiry. While broadening my areas of interest, I work to ensure that every course I develop introduces students to a variety of outstanding political science scholarship. The liberal arts environment has clearly benefited me, and I believe some of the benefits accrued to students as I generated courses not previously available in their institutions and that spoke to areas of student interest. This is one way to think about what is distinctive about teaching in the liberal arts setting, but we must press further.

Let me rehearse some easily anticipated claims about liberal arts and teaching that are neither specific to political science nor to particular subfields within it. "Of course teaching political science in a liberal arts college is distinctive, and it is better for students than taking political science in the big research universities! In research institutions, faculty members are frequently discouraged from investing in undergraduates and undergraduate teaching, also setting up a disincentive to be inventive at the undergraduate level. Liberal arts professors encourage students to question, think, and think outside the box! We are more likely to encourage interesting interdisciplinary work, and we ask broader, better questions than do faculty who are so highly specialized and are expected to be so highly professionalized. We devote more attention to the classroom and students get much more individual guidance and attention. We challenge students more, assign provocative readings, devote more time to our courses, work on writing, and help students grow and make good choices. We don't rely upon teaching assistants and don't use multiple choice exams. Moreover, the peer culture is one in which students expect to take themselves and their work seriously." Some of us have students who made the choice between attending college at Harvard or Yale versus Williams, Amherst, or Swarthmore on the basis of such arguments. There is much to be said for these claims.

The stock counterargument goes generally like this: "Faculty at the best liberal arts colleges cannot crank out as much scholarship as their Research-1 peers. Even 
if some of the faculty produce good work, they cannot participate in as many workshops and conferences. They toil in the trenches without graduate students to help them and without adequate resources or intellectual stimulation. They become generalists rather than specialists. Research-1 professors use their networks to get their best undergraduates into top graduate programs and, by shaping graduate students, help shape the discipline. These professors do what the field recognizes as political science. Liberal arts professors teach it-if they are paying attention to what scholars in the discipline are doing." There is truth in some of these claims as well.

I believe that faculty members at liberal arts institutions quite deliberately do a number of things that make political science teaching different and better for students. Some have already been mentioned. In addition, we move beyond narrow sub-disciplinary "silos" and sometimes draw on cross-disciplinary and interdisciplinary conversations, insights, and work to which we are exposed by our colleagues in the liberal arts college setting. These, too, help position undergraduate students to ask good questions about the presumptions, values, and value of what they encounter in political science classes.

Few members of my department use textbooks, even at the introductory level. We do not demand uniformity (beyond course description) when different departmental members teach their own sections of introductory courses. By constructing their own strategic mix of classic and quite recent scholarship, faculty members build on their strengths. They draw upon timely issues that are of concern to students; deploy provocative but accessible recent scholarly monographs and classic pieces; and draw students to an understanding of political issues, policies, and institutions through tools and approaches within the discipline. In the liberal arts setting, there is lots of room for students to converse with each other and with faculty, recommend web pages and blogs, start an online chat, or argue about class at dinner. Everyone brings their own experiences and other classwork to the table, and we faculty members try to use these as learning tools in discussion. In one of the courses I designed, "Environmental Politics and Policy," students come from backgrounds across the curriculum. Many are natural scientists, and a number have studied environmental issues abroad, so what we have to share is quite interdisciplinary. There is often co-teaching across the generational divide in a liberal arts classroom.

For all of the advantages the liberal arts setting offers for teaching political science, there are things we sometimes may lose sight of. My colleagues in liberal arts colleges maintain a range of views about whether it is a sensible or important goal to prepare students to make sense of political science as a discipline. Opinions often depend on how faculty members feel about trends in the discipline and in their subfields (and these views may be quite negative). I have met liberal arts professors who believe that the chief goals of a political science education 
include getting students to confront their prejudices, understand people unlike themselves, have life transformative experiences through classroom dynamics and encounters, take action in the world on the basis of principles and values, empower themselves, and help others empower themselves. A number of these goals are undeniably important, and these are unlikely to be pursued in many undergraduate classrooms at large research universities. Liberal arts departments tend to make room for at least some such courses.

Attention to the academic discipline of political science, however, remains important for students, and the discipline is capacious enough that there are many ways of attending to this. It is important, for instance, that students understand what sets political science apart from political or legal journalism. Journalists write some very good books; some are extremely good investigators and hard-hitting critics. When we use books and articles by journalists or show documentary films, we need to help students place events, information, and interpretation within frameworks informed by academic scholarship. There is otherwise a danger that students will think of politics in terms of individuals and idiosyncrasies, that they will not think rigorously, and that they will not look for patterns, or, if they do, that they will think of politics in terms of simple dichotomies-for example, the global rich versus global poor; the free versus the unfree. This probably does not move them very far beyond their level of sophistication when they matriculated. There is a danger, perhaps greater in some liberal arts classrooms, of failing to help students understand what the discipline of political science purports to do or can do. If we are critical of our discipline or subfields, would it not be a service to students to bring some of the controversies and their stakes to life?

We should attend to preparing students to make sense of the discipline. I offer courses in American Politics, American Elections, and American Constitutional Law-courses often found in both research universities and liberal arts colleges. I have enormous freedom to decide about courses and content. Is the teaching of such courses different in the two settings? Apart from what I noted above about non-textbook-based teaching, in mid- and upper-level courses, I do not think that my approach to content or subject matter differs from those of many of my colleagues in research universities. I do not think it is in how I choose or put together a syllabus for a course that makes the liberal arts setting different. In these courses, I want students to understand not only what kinds of questions political scientists and theorists ask, but also what it means to try to answer them. Students should see how arguments can revolve around definition of terms ${ }^{1}$ and should

1. In thinking about environmental justice, for example, most political philosophers have treated justice as a relationship among humans. Even if we add cross-generational relationships to that definition, is this sufficient for how we think about forests, fish, and wildlife-that is, that nature be there solely for our grandchildren's use and for human quality of life? And must we think about justice as involving more than the distribution of goods? 
recognize that they must pay attention to how variables are identified, ${ }^{2}$ how measurements are constructed, ${ }^{3}$ and what choices are being made in the presentation of evidence. ${ }^{4}$ Understanding such matters will develop critical thinking skills for good citizenship. And if the student's goal is to change the world and to organize for change, it is very useful to understand what political scientists think that they know about how institutions, organizations, and policy work. Familiarity with the discipline will help those who want to develop effective critiques.

Students should learn that the study of politics is disciplined and requires a certain discipline on their parts. Some students think an essay with a few footnotes is a research paper, and many believe that if they write a paper stating what they think, they have done their job well. It is incumbent on us-and probably requires special attention in liberal arts environments-to model for the students what it means to be systematic. What are the major paradigms, debates, and theoretical frameworks that define a field of study, and how have these changed over time? What counts as a well-constructed argument, and what evidence is needed to sustain it? How does one rule out or reject explanations? This is one reason why methods courses can help the thinking process.

There are certain things we do at Swarthmore as a department that signal a desire to prepare students to make sense of the discipline of political science. One nod to the discipline is the way we organize course offerings and requirements. We continue to identify courses by how they fall within traditional subfield divisions in the discipline-American, theory, international relations, comparative-even while recognizing that a number of courses cross subfields. We note increasing connections between comparative and international subfields and treat these as a single subfield for purposes of our distribution requirements. Although we have not explicitly revisited the rationale for our subfield approach to course offerings in recent years, many other liberal arts departments continue to organize political science or politics offerings in roughly similar ways. We also urge students to do coursework in history, economics, and statistics, in addition to fulfilling field

2. A simple example is in the operationalization of "power." Dahl's definition of power (based on Weber) is highly positivist. Exposing students to controversies among political scientists over how to define and operationalize tests for power is important in helping students develop greater precision in their own claims.

3. For instance, political scientists often deplore voting turnout in American presidential elections. Students need to understand that (1) turnout percentages are higher than often reported if the base is registered voters (which points one's focus to whether barriers to registration should be eliminated), and (2) turnout percentages are higher if the base is voting-eligible population and not voting-age population (which points one's focus to felony disenfranchisement and to how non-citizen immigrants are being counted in calculating the denominator). It is vital to understand these measurement issues in order to know whether there is a problem with turnout, or whether there are other problems that we ought to be discussing.

4. Tables, charts, and graphs tell particular kinds of stories with data. Citizens will be better able to evaluate evidence if they understand how the designer of visual displays chooses to present evidence. 
distribution requirements. Our department wants students to understand politics historically, to become acquainted with the traditions of political thought that have shaped our institutions and political discourse, and to make linkages between the theory and practice of politics. One way to accomplish this latter goal is through courses, both in the department and the college, that are officially recognized for integrating community-based learning. Our emphases reflect some of the important values and emphases in our discipline.

Another way we prepare students to make sense of the discipline is through our honors program, a hallmark of Swarthmore. It consists of double-credit seminars, three in the department and one in a minor, examined by external scholars chosen by seminar instructors. Roughly half of our political science majors participate in this program. Students shoulder a large share of the responsibility for preparing one another for external exams, beginning with the quality of seminar papers and seminar discussions. They learn about major scholars and scholarly debates in a field, frequently present written work, debate issues and interpretations, and develop confidence and strong verbal presentation skills. Not only do honors examiners evaluate individual students, but the department also seeks feedback from honors examiners about how well we are preparing students to understand the field we have defined and covered in our seminars.

Although we currently neither require nor offer a political science research methods course, we would like to find the resources to do so. We would like to see students better trained in both qualitative and quantitative methods. We believe such training would contribute to the rigor of their thinking, would teach students how to make effective demonstrations of their claims, and would help them discern better analyses from worse. Beyond this, a number of our subfields rely increasingly on quantitative work and formal modeling, and our students are currently not well equipped to read, understand, or conduct much of this kind of work. At the moment, we are offering our students two very successful introductory and advanced Geographic Information Systems courses, but they are staffed by a visiting faculty member funded by a short-term grant to the Environmental Studies Program.

There are a few possible ways to introduce more explicit research methods training into the curriculum. One is to hire someone who is well versed in methods and whose teaching responsibilities include some methods courses. A methods course would then be required of undergraduate political science students. Another is to try to teach methods in the context of some of the mid-level substantive courses that we are already teaching-for instance, teaching an introduction to survey research in the context of a course on American elections that has a unit on public opinion or on factors that predict voting behavior. Several of us are trained (or selftrained) in survey research methods, but teaching students in the context of our regular courses means introducing a rigorous "introduction to" research component into a reading-based course. This is extremely arduous in larger classes and in 
an environment in which "lab" sections bearing an extra 0.5 credit are not the norm in the social sciences. If such courses could carry 1.5 rather than 1 creditfor faculty and not simply for students-we might be able to address students' methods needs in this manner.

A number of our colleges are now advertising that they provide research opportunities for undergraduates-summer paid research opportunities, including opportunities to conduct research with faculty members across the curriculum. Colleges such as Swarthmore have increasingly invested in such opportunities. Faculty members are also being encouraged to design some creative researchbased courses or seminars that might advance their own research agendas, but these ventures would come at the expense of other important elements of our curriculum. Sometimes, we are able to employ student research assistants in the summer or during the academic year. In one recent summer, I invited a research assistant to travel with me for work at the National Archives and to help collect data at several archival collections in Chicago. We can provide training and experience in locating and working with particular kinds of data, but we will reach only a small subset of students through such opportunities.

Liberal arts colleges produce a disproportionate share of Ph.D.s awarded to American students. Whether or not formal methods training is supplied, political science is no exception. Swarthmore students do well in gaining admission to top graduate programs in the field, and many become academics. If they are rigorous thinkers, disciplined writers and researchers, and careful readers-all skills we work to develop in liberal arts settings-then they possess many of the skills needed for graduate study. Students in liberal arts settings, because they learn how best to question and interrogate assumptions they encounter in readings and classrooms, also develop the critical-thinking skills necessary for graduate study. However, if political science faculty in liberal arts colleges were not also acquainting students with debates and recent scholarship in the discipline, we would not be seeing the admission rates into top programs that we do. Or, we would see high drop-out rates when our students discover that what they think political science is does not correspond to what the professionals insist it is. And that does not seem to be happening-at least when I look at our graduates.

Of course, political science is about more than preparing students for graduate school or research. It is important that our field help liberal arts students understand politics in the world around them. Interpreting policy proposals, events, conflicts, electoral campaign claims and counterclaims, and weighing political values are among the responsibilities with which democratic citizens are tasked. We have to help students not only understand patterns and why they persist, but also identify (and perhaps participate in) forces of change if they are to become effective actors in the world. 
But here, political science deserves some blame as well as credit. We can only help students understand (and prepare for) change when the discipline is able to! How well did our discipline predict the Arab Spring uprisings or the fall of the Soviet Union and events in Eastern and Central Europe? Did political scientists do well with 9/11, or with the Election of 2000 and the Supreme Court's involvement in it? Do the secular and rationalist presumptions of our discipline help in the understanding of religiously inspired political movements abroad and in the United States? The world does not always conform to disciplinary models, theories, and hypotheses. Political scientists look for patterns in politics and political behavior. When we are confronted with the unexpected, it should be an exciting and fertile time for rethinking. We can and should teach about the limitations of the discipline. Failings and limitations should position liberal arts professors, in particular, to be irreverent about received truths. We can feel free to engage with insights from related disciplines, and can encourage fertile interdisciplinary work. A number of changes we must confront require cross-disciplinary conversations and learning. Liberal arts settings are good places for students to be exposed to these conversations, and here, young political science faculty members probably have more latitude to challenge disciplinary orthodoxies than counterparts in research universities.

Many liberal arts students who take political science classes are highly engaged politically and are reasonably well versed in specific controversies and issues that move them, whether it is mountain-top mining, genocide in Darfur, or electoral politics. Even those less politically engaged have a high degree of intellectual curiosity. Our job includes using our training and disciplinary tools to get students to think and care about political issues they may not have previously considered. It includes teaching them the range of matters that are political questions, and why political science training is "value added." Our job includes using the failures of our models and assumptions for creative thinking.

Our discipline, diverse as it is, is particularly well placed to provoke examination of political values and of competing claims about political goods, and of how competing claims shape politics. We are well placed to examine the successes and failures of liberalism, the trajectory of welfare states, the recent gridlock and divisiveness in American politics, and the place of social movements in politics. Some of us are increasingly well positioned to analyze the drivers and consequences of globalization. Members of our discipline are trained to help students understand reasons for historic policy failures-in the United States and elsewhere - so that, hopefully, the past need not be condemned to repeat itself. While political science is certainly not unique in promoting critical thinking, we are well positioned to promote kinds of critical thinking and enlightened inquiry that will serve attentive and engaged democratic citizens. And a number of our liberal arts graduates will become leaders, playing roles in shaping law, policy, diplomacy, 


\section{LIBERAL ARTS COLLEGES \& POLITICAL SCIENCE}

and the work of non-governmental organizations. If we attend to the kinds of things our profession does well, and call out our profession when it does not do things as well, we will be doing very good political science in a liberal arts college setting indeed. We will be serving a range of students well, and we will make an argument for the continuing relevance of liberal arts. We will, I believe, be doing more for our students than our peers in big research universities can do.

Carol Nackenoff is Richter Professor of Political Science at Swarthmore College, where she teaches American politics, constitutional law, and environmental politics. She is the author of The Fictional Republic: Horatio Alger and American Political Discourse (1994), and co-editor of Statebuilding from the Outside In (2014) and Jane Addams and the Practice of Democracy (2009). Her current work examines the role of female-dominated progressive era organizations in building the American state. She may be reached at cnacken1@swarthmore.edu. 